\title{
Two amphibian diseases, chytridiomycosis and ranaviral disease, are now globally notifiable to the World Organization for Animal Health (OIE): an assessment
}

\author{
Lisa M. Schloegel ${ }^{1,2, *}$, Peter Daszak ${ }^{1,2, * *}$, Andrew A. Cunningham ${ }^{3, * *}$, \\ Richard Speare ${ }^{4, * *}$, Barry Hill ${ }^{5, * *}$ \\ ${ }^{1}$ Wildlife Trust, 460 West 34th Street, 17th Floor, New York, New York 10001, USA \\ ${ }^{2}$ School of Life Sciences, Kingston University, Kingston-upon-Thames, Surrey KT1 2EE, UK \\ ${ }^{3}$ Institute of Zoology, Zoological Society of London, Regent's Park, London NW1 4RY, UK \\ ${ }^{4}$ Amphibian Diseases Ecology Group, School of Public Health, Tropical Medicine and Rehabilitation Services, \\ James Cook University, Townsville, Queensland 4811, Australia \\ ${ }^{5}$ Centre for Environment, Fisheries and Aquaculture Science, Barrack Road, Weymouth DT4 8UB, UK
}

\begin{abstract}
The global trade in amphibians entails the transport of tens of millions of live animals each year. In addition to the impact harvesting wild animals can have on amphibian populations, there is mounting evidence that the emerging pathogens Batrachochytrium dendrobatidis and ranaviruses, the aetiological agents of chytridiomycosis and ranaviral disease, respectively, are spread through this trade. The link between these pathogens and amphibian declines and extinctions suggests that the epidemiological impact of the trade is significant and may negatively affect conservation and trade economics. Here we present a brief assessment of the volume of the global trade in live amphibians, the risk of individuals harboring infection, and information on the recent listing by the World Organization for Animal Health (OIE) of chytridiomycosis and ranaviral disease in the OIE Aquatic Animal Health Code. This listing made chytridiomycosis and ranaviral disease internationally notifiable diseases and thus subject to OIE standards, which aim to assure the sanitary safety of international trade in live amphibians and their products.
\end{abstract}

KEY WORDS: OIE $\cdot$ Amphibian trade $\cdot$ Notifiable disease $\cdot$ Chytridiomycosis $\cdot$ Ranavirus Resale or republication not permitted without written consent of the publisher

\section{INTRODUCTION}

According to the Global Amphibian Assessment (GAA), $43 \%$ of amphibian populations are currently in decline, and $32 \%$ are threatened with extinction (Stuart et al. 2004). Recent research has identified 2 diseases that have been implicated in a global increase in amphibian mortality: chytridiomycosis, an emerging fungal disease caused by the pathogen Batrachochytrium dendrobatidis, and ranaviral disease (family Iridoviridae), an emerging viral disease caused by ranaviruses (Berger et al. 1998, Daszak et al. 2003, Lips et al. 2006). A series of papers has discussed the likely origin of these pathogens and the causes of their emergence; many implicating the international trade in amphibians for food, pets, ornamental garden animals, scientific research, introduced or released animals, and zoo animals (Daszak et al. 1999, 2003, Mutschmann et al. 2000, Garner et al. 2006, Fisher \& Garner 2007). However, debates on the relative importance of trade and other drivers of amphibian disease emergence continue (Lips et al. 2008).

In an effort to assess growing concern about the spread of these diseases, their potential impact on wild and farmed amphibian populations, and the trade in live amphibians and amphibian products, the World 
Organization for Animal Health (OIE) (www.oie.int) in 2006 formed the ad hoc Group on Amphibian Diseases to report to and advise the OIE Aquatic Animal Health Standards Commission, one of the OIE Specialist Commissions.

The OIE publishes, and regularly updates, the Aquatic Animal Health Code (Aquatic Code), which aims to assure the sanitary safety of international trade in aquatic animals (amphibians, crustaceans, fish, and mollusks) and their products. The World Trade Organization, under the Sanitary and Phytosanitary (SPS) Agreement recognizes the OIE as the international standard setting body for international trade in animals and animal products. The OIE is placed under the authority and control of the World Assembly of Delegates comprising national representatives designated by the governments of all 174 (as of April 2009) member countries and territories. The World Assembly of Delegates is the decision-making body of the OIE, and operates on the basis of 'one country, one vote'. A primary goal of the OIE is to promote animal health through the development of international standards (particularly those concerning international trade) and to adopt resolutions overseeing the management of animal diseases that could negatively impact animal or human health.

Ad hoc groups are formed on an as-needed basis to carry out technical work to inform the relevant Specialist Commission on the development of recommendations for inclusion in the OIE standards. Participants of ad hoc groups are internationally recognized specialists within their field of study.

Members appointed to the OIE's ad hoc Group on Amphibian Diseases have expertise in amphibian disease and declines and comprise Dr. Barry Hill from the Centre for Environment, Fisheries and Aquaculture Science, UK; Dr. Andrew Cunningham from the Institute of Zoology, UK; Dr. Peter Daszak from Wildlife Trust, USA; and Dr. Richard Speare from James Cook University, Australia. The primary task of the ad hoc group was to review both the published scientific literature on transmissible diseases in amphibians and the evidence for their transfer by international trade in live amphibians and their products or by other means. The group then recommends whether OIE standards should be developed for international trade in amphibians. In the present study, we discuss the information examined by the ad hoc group on the international amphibian trade and on the amphibian diseases chytridiomycosis and ranaviral disease. This led to a recommendation that these 2 diseases be listed in the Aquatic Code, which requires reporting their occurrence to the OIE and implementation of the OIE recommendations to limit the spread of these pathogens through trade routes.

\section{LITERATURE REVIEW}

The scale of the international trade in amphibians is extensive, with the sale of frogs for human consumption and for pets being a commercial business in many regions (Parker 2004, Warkentin et al. 2009). In addition to the food and pet trades, amphibians are transported regionally and internationally for the bait trade, for experimental use in laboratories, as exhibits in zoological institutions, and for bio-control purposes. Each of these trade routes carries the risk of disseminating amphibian pathogens should shipments contain infected individuals.

In 2005 the total recorded value of the global market for frogs legs amounted to US\$ 43298 000, with France, Belgium, and the United States listed as the top countries of import (Parker 2004). Nations from Europe, North America, Asia, Latin America, Africa, and the Middle East are all reported to participate in the trade in frog legs. From the years 1998 to 2002, more than 3.8 million whole frogs and more than 2.8 million $\mathrm{kg}$ of the North American bullfrog Rana catesbeiana were imported into the United States for the food trade (L. M. Schlaepfer et al. 2005). Data obtained from the US Fish and Wildlife Service Law Enforcement Management Information System database on wildlife importations indicate that $488315 \mathrm{~kg}$ and 4586299 live amphibians were traded across US borders in 2006 alone (L. M. Schloegel et al. unpubl. data).

A survey of North American bullfrogs farmed abroad and imported live into the United States and sold at markets in 3 major US cities detected frogs that tested positive for both Batrachochytrium dendrobatidis and ranaviruses (Schloegel et al. 2009). Should these infected individuals escape the confines of the farms and/or markets or interact with free-living species (e.g. through wild frogs entering ponds of farmed frogs), native amphibians could be at risk of infection. The emergence of chytridiomycosis in the UK, for example, was associated with infected, feral, North American bullfrogs (Cunningham et al. 2005). Invasive populations of the North American bullfrog have been documented across 4 continents, including Europe, North and South America, and Asia: of these, the majority of populations tested are positive for B. dendrobatidis (Hanselmann et al. 2004, Garner et al. 2006, Yang et al. 2009).

Two other species that warrant cause for concern are the African clawed frog Xenopus laevis and the cane toad Bufo marinus. The detection of Batrachochytrium dendrobatidis infection in a 1938 X. laevis museum specimen led to the speculation that the fungus originated in Africa and was distributed to varying regions of the world through the international transport of these anurans (Weldon et al. 2004). X. laevis was 
traded widely for use in human pregnancy testing throughout the 1930s and 1940s. This species later became the most common amphibian species used in laboratory research, with more than 71500 animals shipped out of Africa between the years 1998 and 2004 (Weldon et al. 2007). The cane toad B. marinus was also used in pregnancy assays, although this species is more widely known for its intentional introduction into Australia and many other countries as a bio-control measure. Wild cane toads are known to be infected with ranaviruses within their native range (Zupanovic et al. 1998a), and feral cane toads in Australia test seropositively for ranaviruses (Zupanovic et al. 1998b). Furthermore, captive-bred cane toads have been shown to harbor high rates of $B$. dendrobatidis infection, and infection has been detected in captive-bred animals at zoological institutions and occasionally in the wild (Berger et al. 1998, 1999).

Infection with Batrachochytrium dendrobatidis has been reported in additional captive populations around the world (Berger et al. 1999, Longcore et al. 1999, Mazzoni et al. 2003, Une et al. 2008, Marantelli et al. 2004, Schloegel et al. 2009). Many zoological institutions are currently involved in the captive breeding of amphibians for species re-introduction programs. From a conservation standpoint, the release of captivereared individuals to recover depleted wild populations is a valuable effort. However, this increases the risk of introducing alien pathogens that could negatively impact wildlife health. The reintroduction of the Mallorcan midwife toad using captive-bred animals, for instance, appears to have introduced B. dendrobatidis to Mallorca (Walker et al. 2008).

The pet trade has the potential to lead to species and pathogen introductions through the release of unwanted pets. Amphibian diseases and alien invasions have already been documented in various pet trade species (Berger et al. 1999, Mutschmann et al. 2000, Weldon et al. 2004, Lobos \& Jaksic 2005, Hou et al. 2006, Fisher \& Garner 2007). In Japan, Batrachochytrium dendrobatidis infections were found in 9 exotic amphibian species kept by a private breeder, the first published case of the pathogen in Asia (Une et al. 2008). Recent studies have highlighted the bait trade in the United States as a pathway for amphibian disease spread. Outbreaks of Ranavirus throughout the western USA have been linked to the trafficking across state boundaries of the tiger salamander Ambystoma tigrinum for use as fishing bait (Jancovich et al. 2005). These animals are immersed directly into amphibian habitat, and the potential for disease spread has been confirmed by recent studies (Picco \& Collins 2008).

It has become increasingly evident that the international trade can have damaging effects on the health and persistence of amphibian populations worldwide.
While new data has come to light in recent years, there is still much that remains unknown. Given the threatened status of many amphibian species and the apparent risks associated with the international transport of live animals, additional consideration should be given to the extent of the amphibian trade and what can be done to reduce the hazards of the international movement of amphibian pathogens.

\section{QUESTIONNAIRE}

To assess current trends, the OIE ad hoc group drafted a questionnaire, which was disseminated to all OIE members in 2006 (Box 1). The survey contained questions on the production, exportation, and importation of amphibians (including the presence of any known amphibian pathogens) for each of the participating countries and regions. A response was received from 69 (of 172 members; 40\%) OIE members. The geographical distribution of the respondents included 13 from the Americas, 9 from Africa, 33 from Europe, 10 from Asia/Far East, and 4 from the Middle East.

A total of 45 of the 69 (65\%) respondents reported that they currently trade in amphibians, 30 of which import/export live specimens; 28 trade in amphibians for human consumption, 30 for pets, 22 for experimen-

Box 1. Synopsis of the questionnaire disseminated to the World Organization for Animal Health (OIE) members in 2006 with respect to the international trade in amphibians. CITES: Convention on International Trade in Endangered Species

OIE questionnaire overview

Does your country trade in amphibians or amphibian products? If so, what is the nature of the trade (human, lab, pet, zoo, other)?

Annual size of international trade in live amphibians (number of individuals and/or total weight and/or total value) for imports and exports of both farmed and wild amphibians.

Annual size of international trade in amphibian products (number of individuals and/or total weight and/or total value) for imports and exports of both farmed and wild amphibians.

Does your country farm amphibians? If so, list the number of farms in your country and the total production.

Have any amphibian diseases been reported in your country? If so, indicate which disease(s).

Other than for CITES purposes, does your country have legislation covering amphibian trade?

Does your country have legislation covering amphibian disease issues?

In your view, should the remit of the OIE be extended to included amphibian diseases? 
tal/laboratory use, and 26 for zoological purposes. Nineteen $(28 \%)$ respondents reported that they participated in the commercial farming of amphibians. Of the 45 countries trading in amphibians, 31 provided quantitative data on the extent of their trade. Data were provided in weight $(\mathrm{kg})$ or numbers of individual animals, except in one case where the data were reported solely in terms of monetary value. For live amphibians, $508743 \mathrm{~kg}$ and 1577128 individuals were imported, and $321317 \mathrm{~kg}$ and 5085060 individuals were exported (Table 1). For amphibian products, $3660971 \mathrm{~kg}$ and 1522 individuals were imported, and $875451 \mathrm{~kg}$ were exported (Table 2).

Since the \% response from members (40\%) was less than considered optimal for surveys, the data may not be representative of all members. Data provided were often unsubstantiated and often did not correspond with numbers obtained from other sources, such as federal and published data. According to the survey responses, for instance, the collective live imports into the Americas tallied a total of 429 individuals. US federal trade data, however, puts the total number of live amphibian imports into the United States alone in 2006 at more than $400000 \mathrm{~kg}$ and 4500000 individuals (L. M. Schloegel et al. unpubl. data). Such discrepancies in reporting reflect the need for a standardized system to monitor the import and export of amphibians at international ports to adequately assess the risk of disease transmission and spread.

Diseases were documented in traded amphibians by 14 respondents, 8 of which specifically cited Batrachochytrium dendrobatidis and/or ranavirus infections. This is likely an underestimate of the number of countries in which these pathogens are actually present. Disease surveillance has not been conducted in all countries responding to the survey. In addition, the presence of these pathogens has been documented in the scientific literature for a number of members who provided no disease data in response to the OIE questionnaire. The majority of respondents indicated that their countries do not currently have established legislation on amphibian diseases (56 members; 82\%) (Fig. 1). In response to whether the OIE's remit should be expanded to include amphibian diseases, 49 (70\%) of respondents replied in the affirmative (Fig. 1).

\section{OIE DECISION}

In light of these and other findings, the OIE ad hoc group advised the OIE Aquatic Animal Health Standards Commission that infection with Batrachochytrium dendrobatidis and infection with ranavirus fulfilled the listing criteria laid down in the Aquatic Code and recommended that these diseases be listed in the Aquatic Code and made notifiable to the OIE. A notifiable disease is one whose detection must, by mandate, be notified by the competent veterinary authority to the OIE as required under Chapter 1.1 of the Aquatic Code. OIE members would also be required to report the presence or absence of each disease in their territory on a semi-annual basis, and ensure disease surveillance programs are implemented to support any claims of freedom from one or both diseases. The recommendation was accepted by the commission, who then proposed it for adoption. And at the OIE General Session in May 2008, the OIE World Assembly of Delegates unanimously approved the addition of these pathogens to the OIE list of aquatic animal diseases. This was subsequently implemented in the 2008 edition of the Aquatic Code (World Organisation for Animal Health 2008).

\begin{tabular}{lccclc}
\hline America & 22306 & 0 & 2000 & 0 & 3 \\
Africa & 303 & 0 & 0 & 0 & 1 \\
Europe & 3598212 & 0 & 358300 & 0 & 8 \\
Asia-Far East & 39150 & 1522 & 515151 & 0 & 5 \\
Middle East & 1000 & 0 & 0 & 0 & 1 \\
Total & 3660971 & 1522 & 875451 & 0 & 16 \\
\hline
\end{tabular}


(A) Legislation on amphibian diseases?

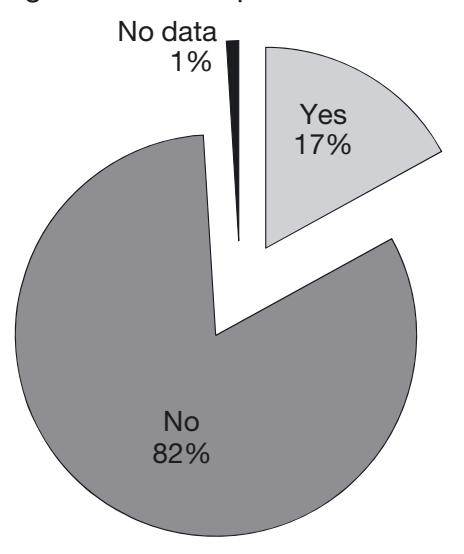

(B) OIE's remit to include amphibian diseases?

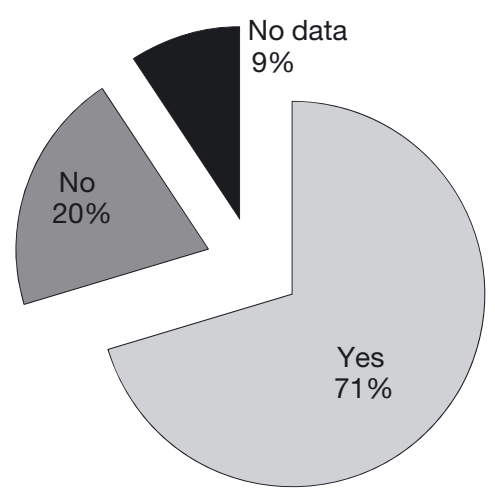

Fig. 1. Percent of respondents indicating (A) if legislation on amphibian diseases existed in their country as of 2006 and (B) whether they are of the opinion that the World Organization for Animal Health's (OIE) remit should be expanded to include amphibian diseases

\section{IMPLICATIONS AND RECOMMENDATIONS}

Professionals and other persons engaged in the production, transport, and receipt of amphibians are often unaware of the fact that their animals/shipments may be carrying pathogens and of the potential consequences that can arise as a result of contamination. The distribution of knowledge and increased awareness of the devastating effects of spreading Batrachochytrium dendrobatidis and ranaviruses through the amphibian trade is a major step towards global disease management. OIE standards are designed to ensure that the most up-to-date information on the presence or absence of animal diseases representing a significant threat to animal, or even human, health are readily available so that appropriate measures can be taken.

In the case of Batrachochytrium dendrobatidis and ranaviruses, cautionary measures include the treatment of individuals and wastes that will render the pathogen inactive, or the direct delivery of infected animals to a lifelong holding, biosecure facility (www.oie.int/eng/normes/fcode/a_summry.htm). Animals intended for the food trade should be immediately transported to a processing facility and quarantined until such time that they are slaughtered and subsequently converted into one of several recommended products. These are products that inactivate the disease agents and include canned or dried products, leather products, skinned carcasses or legs, and preserved biological specimens.

Water wastes, containers/enclosures, and any other surface that has come into contact with an amphibian should be disinfected prior to disposal. A number of antiseptic techniques are currently available for the sterilization of wastes and surfaces, including the application/soaking of over-the-counter bleach with a sodium hypochlorite concentration of $1 \%$ and above for Batrachochytrium dendrobatidis and $3 \%$ and above for ranaviruses (Johnson et al. 2003, OIE 2007, Webb et al. 2007, Bryan et al. 2009).

An exporting country may issue an international aquatic animal health certificate if animals and/or animal products have been treated for and proven free from infection prior to export. Quarantine and treatment of individuals should be utilized when animals are imported for the pet trade, for laboratory use, and for zoological purposes, among others. Possible treatments of individuals for Batrachochytrium dendrobatidis include the topical application of various chemical agents (e.g. the antifungal drug itraconazol), as well as short-term, elevated body temperature (Nichols \& Lamirande 2001, Retallick \& Miera 2007. Woodhams et al. 2008, Garner et al. 2009). While each of these methods has a high success rate, limitations do exist. The test species for the elevated temperature regime, for instance, was tropical tree frog Litoria chloris from Australia, a species that is able to withstand high temperatures. A lower temperature of $32^{\circ} \mathrm{C}$ for $5 \mathrm{~d}$ was used to clear $B$. dendrobatidis from a temperate species, Pseudacris triseriata (Retallick \& Miera 2007). However, these limited experimental studies on the effect of heat to kill $B$. dendrobatidis have not been developed into strategies that can treat large shipments of amphibians, particularly for frogs in the food and pet trade. This needs to be done urgently.

The use of both temperature and antifungal solutions to cure Batrachochytrium dendrobatidis infection may prove useful when a small number of individuals require treatment at any given point in time. Considering the large number of animals in the various trades (particularly the food trade), however, these regimens may lose their feasibility when accounting for time, space, and monetary constraints. Additionally, there is the added issue of whether chemical treatments are 
safe to be used on animals intended for human consumption. For example, one study has shown the antimicrobial, chloramphenicol, to be efficacious against $B$. dendrobatidis infection (Bishop et al. 2009), but there is much controversy surrounding the acceptable daily intake (ADI) of chloramphenicol and its use in animals intended for human consumption (Hanekamp \& Calabrese 2007, Wongtavatchai et al. 2009).

A recent study of North American bullfrogs imported for the food trade and sold live in US markets found a high (62\%) prevalence of Batrachochytrium dendrobatidis infection (Schloegel et al. 2009). This figure is alarming, especially when considering the absence of an approved treatment for this pathogen in food stock. There is a current ban on the importation of live, North American bullfrogs into Europe due to their invasiveness (Scalera \& Zaghi 2004). Thus, all North American bullfrog imports into Europe for the food trade are in the form of frozen, skinned frogs legs, a recommended product by the OIE Aquatic Code that does not appear to pose a risk to the transport of amphibian pathogens between countries. The European importation ban of live North American bullfrogs could serve as a model to other countries seeking to minimize the importation of amphibian pathogens while not obstructing the food trade altogether.

Treatments for ranavirus infection do not currently exist, which poses additional impediments to amphibian disease management. The prevalence of ranaviruses in trade amphibians has been shown to fluctuate greatly among populations of the same species, with evidence of seasonal variability (Picco \& Collins 2008, Schloegel et al. 2009). Further investigations on infection prevalences within, and transmission rates amongst, trade species is necessary to adequately assess the risk of pathogen spread. Any animals used for the startup of future captive colonies should be tested for both ranavirus and Batrachochytrium dendrobatidis infections with the intent of developing disease-free stocks, where possible. Detection of ranaviruses typically requires destruction of the host, but a recent study successfully used biopsies of tails in salamanders (Greer \& Collins 2007). The positive predictive value of this technique, however, may be lower than destructive testing, and prevalence may be underestimated. Furthermore, a large proportion of amphibians in the pet and zoological trades are still taken from the wild. Special care and consideration should be given to the handling of these individuals, including quarantine and testing. Clientele should be informed of the origin and health history of their animals and should be warned against the dangers of spreading pathogens to native amphibians. PetWatch, for example, is a United States-based consumer information campaign aimed at informing the public about healthy pet choices, including amphibians (http:// katesmithlab.googlepages.com/wildlifetrade2). Based on the most recent scientific findings, PetWatch collates data on trade species and makes recommendations for 'good pet choices' and references both B. dendrobatidis and ranaviruses in the case of amphibians.

The mounting evidence indicating that Batrachochytrium dendrobatidis and ranaviruses are present in the international trade in live amphibians, and the unanswered questions as to the extent of their presence, are cause for concern. Experimental research has shown differences in the pathogenicity of different isolates of $B$. dendrobatidis (Berger et al. 2005, Retallick \& Miera 2007, Fisher et al. 2009). These data indicate that the introduction of a highly virulent strain could have important implications should it be introduced into naïve populations or into populations infected only with a low-virulent strain. Additional studies should be conducted with trade isolates to determine the degree of damage that could result from their movement into new regions. Furthermore, numerous factors are capable of influencing transmission at an animal's origin, during transit and at the final destination, including temperature, animal density, water quality, and stress. Simulated experiments in a laboratory setting could provide insight into the rate at which inter- and intra-species transmission can occur given certain environmental conditions and/or stressors, as well as the severity of disease and time to death in various trade species.

A better understanding of how environmental and host conditions influence pathogen virulence and prevalence (and the changes in prevalence along trade routes) can allow for the development of management practices to minimize transmission and the number of infected individuals within the amphibian trade, thereby decreasing the risk of pathogen spread. The pet industry is becoming increasingly aware of the potential dangers of Batrachochytrium dendrobatidis infection in traded, live amphibians and actions are already being taken for the promotion of safe husbandry practices, including the Pet Industry Joint Advisory Council's (PIJAC) Bd-Free 'Phibs campaign in the United States (www.pijac.org/projects/project. asp? $p=26$ ), which is open to participation from all entities maintaining amphibian populations ex situ.

With millions of amphibians being traded on an annual basis, and documented infections in wild and farmed animals (particularly in the North American bullfrog), the current lack of disease control protocols requires urgent attention (Mazzoni et al. 2003, Schlaepfer et al. 2005, Garner et al. 2006, Schloegel et al. 2009). Disease surveillance should be conducted on an international scale at regular intervals to aid risk assessments. Strict quarantine and surveillance pro- 
grams should be enacted to monitor the movement of infected individuals, ensuring that all parties are equipped to ensure proper handling and care. Furthermore, OIE standards should serve as a foundation for developing national and international policy to mitigate the further spread of amphibian pathogens through international trade.

Acknowledgements. Work towards this review was supported primarily by the OIE. We also acknowledge funding from The New York Community Trust, the Eppley Foundation, and the National Science Foundation (IRCEB grant DEB02133851).

\section{LITERATURE CITED}

Berger L, Speare R, Daszak P, Green DE and others (1998) Chytridiomycosis causes amphibian mortality associated with population declines in the rain forests of Australia and Central America. Proc Natl Acad Sci USA 95: 9031-9036

Berger L, Speare R, Hyatt A (1999) Chytrid fungi and amphibian declines: overview, implications and future directions. In: Campbell A (ed) Declines and disappearances of Australian frogs. Environment Australia, Canberra, p 23-33

Berger L, Marantelli G, Skerratt LF, Speare R (2005) Virulence of the amphibian chytrid fungus Batrachochytrium dendrobatidis varies with the strain. Dis Aquat Org 68: 47-50

Bishop PJ, Speare R, Poulter R, Butler M and others (2009) Elimination of Batrachochytrium dendrobatidis by Archey's frog Leiopelma archeyi. Dis Aquat Org 84:9-15

Bryan LK, Baldwin CA, Gray MJ, Miller DL (2009) Efficacy of select disinfectants at inactivating Ranavirus. Dis Aquat Org 84:89-94

> Cunningham AA, Garner TWJ, Anguilar-Sanchez V, Banks B and others (2005) The emergence of amphibian chytridiomycosis in Britain. Vet Rec 157:386-387

Daszak P, Berger L, Cunningham AA, Hyatt AD, Green DE, Speare R (1999) Emerging infectious diseases and amphibian population declines. Emerg Infect Dis 5: 735-748

Daszak P, Cunningham AA, Hyatt AD (2003) Infectious disease and amphibian population declines. Divers Distrib 9:141-150

- Fisher MC, Garner TWJ (2007) The relationship between the emergence of Batrachochytium dendrobatidis, the international trade in amphibians and introduced amphibian species. Fungal Biol Rev 21:2-9

Fisher MC, Bosch J, Yin Z, Stead DA and others (2009) Proteomic and phenotypic profiling of the amphibian pathogen Batrachochytrium dendrobatidis shows that genotype is linked to virulence. Mol Ecol 18:415-429

Garner TWJ, Perkins MW, Govindarajulu P, Seglie D, Walker S, Cunningham AA, Fisher MC (2006) The emerging amphibian pathogen Batrachochytrium dendrobatidis globally infects introduced populations of the North American bullfrog, Rana catesbeiana. Biol Lett 2:455-459

Garner TWJ, Garcia G, Carroll B, Fisher MC (2009) Using itraconazole to clear Batrachochytrium dendrobatidis infection, and subsequent depigmentation of Alytes muletensis tadpoles. Dis Aquat Org 83:257-260

Greer AL, Collins JP (2007) Sensitivity of a diagnostic test for amphibian Ranavirus varies with sampling protocol. J Wildl Dis 43:525-532
Hanekamp JC, Calabrese JC (2007) Chloramphenicol, European legislation and homesis-commentary. Dose Response 5:91-93

Hanselmann R, Rodriguez A, Lampo M, Fajardo-Ramos L and others (2004) Presence of an emerging pathogen of amphibians in introduced bullfrogs Rana catesbeiana in Venezuela. Biol Conserv 120:115-119

Hou PCL, Shiau TW, Tu MC, Chen CC and others (2006) Exotic amphibians in the pet shops of Taiwan. Taiwania 51:1-7

Jancovich JK, Davidson EW, Parameswaran N, Mao J and others (2005) Evidence for emergence of an amphibian iridoviral disease because of human-enhanced spread. Mol Ecol 14:213-224

Johnson ML, Berger L, Philips L, Speare R (2003) Fungicidal effects of chemical disinfectants, UV light, dessication and heat on the amphibian chytrid, Batrachochytrium dendrobatidis. Dis Aquat Org 57:255-260

- Lips KR, Brem F, Brenes R, Reeve JD and others (2006) Emerging infectious disease and the loss of biodiversity in a neotropical amphibian community. Proc Natl Acad Sci USA 103:3165-3170

> Lips KR, Diffendorfer J, Mendelson JR, Sears MW (2008) Riding the wave: reconciling the roles of disease and climate change in amphibian declines. PLoS Biol 6:e72

Lobos G, Jaksic FM (2005) The ongoing invasion of African clawed frogs (Xenopus laevis) in Chile: causes of concern. Biodivers Conserv 14:429-439

> Longcore JE, Pessier AP, Nichols DK (1999) Batrachochytrium dendrobatidis gen. et sp. nov., a chytrid pathogenic to amphibians. Mycologia 91:219-227

Marantelli G, Berger L, Speare R, Keegan L (2004) Changes in distribution of Batrachochytrium dendrobatidis and keratin during tadpole development leading to high mortality after metamorphosis. Pac Conserv Biol 10:173-179

> Mazzoni R, Cunningham AA, Daszak P, Apolo A, Perdomo E, Speranza G (2003) Emerging pathogen of wild amphibians in frogs (Rana catesbeiana) farmed for international trade. Emerg Infect Dis 9:995-998

Mutschmann F, Berger L, Zwart P, Gaedicke C (2000) Chytridiomykose bei Amphibian-erstmaliger Nachweis für Europa. Berl Munch Tierarztl Wochenschr 113: 380-383 (in German)

Nichols DK, Lamirande EW (2001) Successful treatment of chytridiomycosis. Froglog 46:1

OIE (2007) Infection with Ranavirus. www.oie.int/aac/eng/ Publicat/Cardsenglish/Ranavirus \% 20card_final.pdf. (accessed 29 July 2009)

Parker PM (2004) The world market for frogs' legs: a 2005 global trade perspective. ICON Group, San Diego, CA, p $1-39$

Picco AM, Collins JP (2008) Amphibian commerce as a likely source of pathogen pollution. Conserv Biol 22:1582-1589

Retallick RWR, Miera V (2007) Strain differences in the amphibian chytrid Batrachochytrium dendrobatidis and non-permanent, sub-lethal effects of infection. Dis Aquat Org 75:201-207

Scalera R, Zaghi D (2004). Life III: alien species and nature conservation in the EU. European Communities, Luxembourg

Schlaepfer MA, Hoover C, Dodd CK (2005) Challenges in evaluating the impact of the trade in amphibians and reptiles on wild populations. Bioscience 55:256-264

> Schloegel LM, Picco A, Kilpatrick AM, Davies AJ, Hyatt A, Daszak P (2009) Magnitude of the US trade in amphibians and presence of presence of Batrachochytrium dendrobatidis and Ranavirus infection in imported North 
American bullfrogs (Rana catesbeiana). Biol Conserv 142: $1420-1426$

Stuart SN, Chanson JS, Cox NA, Young BE, Rodrigues ASL, Fishcman DL, Waller RW (2004) Status and trends of amphibian declines and extinctions worldwide. Science 306:1783-1786

Une Y, Kadekaru S, Tamukai K, Goka K, Kuroki T (2008) First report of spontaneous chytridiomycosis in frogs in Asia. Dis Aquat Org 82:157-160

Walker SF, Bosch J, James TY, Litvintseva AP and others (2008) Invasive pathogens threaten species recovery programs. Curr Biol 18:r853-r854

Warkentin IG, Bickford D, Sodhi NS, Bradshaw CJA (2009) Eating frogs to extinction. Conserv Biol 23:1056-1059

Webb R, Mendez D, Berger L, Speare R (2007) Additional disinfectants effective against the amphibian chytrid fungus Batrachochytrium dendrobatidis. Dis Aquat Org 74:13-16

Weldon C, du Preez LH, Hyatt AD, Muller R, Speare R (2004) Origin of the amphibian chytrid fungus. Emerg Infect Dis 10:2100-2105

Weldon C, De Villiers AL, Du Preez LH (2007) Quantification of the trade in Xenopus laevis from South Africa, with implications for biodiversity conservation. Afr J Herpetol $56: 77-83$

Editorial responsibility: Alex Hyatt,

Geelong, Victoria, Australia
Wongtavatchai J, McLean JG, Ramos F, Arnold D (2009) Chloramphenicol (WHO Food Additives Series 53). www.inchem.org/documents/jecfa/jecmono/v53je03.htm. (accessed 5 May 2009)

> Woodhams DC, Alford RA, Marantelli G (2003) Emerging disease of amphibians cured by elevated body temperature. Dis Aquat Org 55:65-67

World Organisation for Animal Health (2008) Diseases listed by the OIE. Chapter 1.2.3, article 1.2.3.4. In: Aquatic Animal Health Code 2008. OIE, Paris

Yang H, Baek H, Speare R, Webb R and others (2009) First detection of the amphibian chytrid fungus Batrachochytrium dendrobatidis in free-ranging populations of amphibians on mainland Asia: survey in South Korea. Dis Aquat Org 86:9-13

Zupanovic Z, Musso C, Lopez G, Louriero CL, Hyatt AD, Hengstberger S, Robinson AJ (1998a) Isolation and characterization of iridoviruses from the giant toad Bufo marinus in Venezuela. Dis Aquat Org 33:1-9

> Zupanovic Z, Lopez G, Hyatt A, Shiell BJ, Robinson AJ (1998b) An improved enzyme linked immunosorbent assay for detection of anti-Ranavirus antibodies in the serum of the giant toad (Bufo marinus). Dev Comp Immunol 22:573-585

Submitted: January 15, 2009; Accepted: September 1, 2009 Proofs received from author(s): December 30, 2009 